\title{
Histologi Organ Hepatopankreas Kepiting Bakau (Scylla serata) pada Konsentrasi Sublethal Fenol sebagai Peringatan Dini (Early warning) Toksisitas Fenol di Estuaria
}

\author{
Alfi Hermawati Waskita Sari ${ }^{1 *}$, Yenny Risjani ${ }^{1}$, Agung Pramana Warih Marhendra ${ }^{2}$ \\ ${ }^{1}$ Fakultas Perikanan dan Ilmu Kelautan, Universitas Brawijaya \\ 2Jurusan Biologi, Fakultas Matematika dan Ilmu pengetahuan Alam, Universitas Brawijaya
}

\begin{abstract}
Abstrak
Fenol dan senyawa fenolik merupakan salah satu xenobiotik yang menjadi salah satu faktor stres lingkungan pada biota yang terpapar dan telah menjadi masalah lingkungan akibat dampak antropogenik lingkungan. Konsentrasi fenol yang melebihi batas ambang ke dalam ekosistem perairan dapat menjadi stresor kimia bagi organisme akuatik, termasuk kepiting bakau (Scylla serata). Teknik histologi juga merupakan salah satu metode umum yang dapat digunakan untuk mengetahui efek sublethal polutan. Sebelum menetapkan konsentrasi sublethal, terlebih dahulu dilakukan penentuan konsentrasi $\mathrm{LC}_{50}(96 \mathrm{jam})$. Berdasarkan data mortalitas dari hasil uji toksisitas akut $\mathrm{LC}_{50}$ (96 jam) fenol terhadap kepiting bakau (Scylla serata) yang dianalisis dengan analisis probit, diperoleh konsentrasi LC ${ }_{50}(96$ jam) sebesar $26 \mathrm{mg} . \mathrm{L}^{-1}$. Dari hasil tersebut kemudian ditentukan perlakuan konsentrasi sublethal fenol (96 jam) yang dilakukan, yakni perlakuan A $\left(1,62 \mathrm{mg} \cdot \mathrm{L}^{-1}\right), \mathrm{B}\left(6,5 \mathrm{mg} \cdot \mathrm{L}^{-1}\right), \mathrm{C}\left(13 \mathrm{mg} \cdot \mathrm{L}^{-1}\right)$ serta kontrol. Hasil pengamatan pada akhir perlakuan diketahui terdapat perbedaan yang signifikan terhadap histologi organ insang dan hepatopankreas pada tiap perlakuan dimana pada konsentrasi yang semakin tinggi menunjukkan kerusakan jaringan yang semakin terlihat jelas pada hepatopankreas juga terlihat perubahan yang signifikan yang terlihat pada tubulus hepatopankreatik kepiting bakau (S. serata) yaitu vakuola lebih terbentuk, epitel tampak tidak teratur, hilangnya bentuk bintang pada lumen.
\end{abstract}

Kata Kunci : fenol, hepatopankreas, kepiting bakau.

\section{Abstract}

Phenols and phenolic compounds is one of xenobiotics which became one of the environmental stress factors on biota exposed and have become environmental problems due to anthropogenic environmental impacts. Phenol concentrations that exceed the threshold into the aquatic ecosystem can be a chemical stressors to aquatic organisms, including also for the mud crab (Scylla serata). Histological technique is also one of the common methods used to determine the sublethal effects of pollutants. Before setting sublethal concentrations, first performed the determination of the concentration $\mathrm{LC}_{50}$ (96 hours). Based on mortality data from the test results of acute toxicity $\mathrm{LC}_{50}$ (96 hours) phenol of mangrove crab (S. serata) are processed using probit analysis, obtained by concentration $\mathrm{LC}_{50}$ (96 hours) at $26 \mathrm{mg} \cdot \mathrm{L}^{-1}$. From the results of treatment are then determined sublethal concentrations of phenol (96 hours) is performed, ie, treatment $A\left(1.62 \mathrm{mg} \cdot \mathrm{L}^{-1}\right), \mathrm{B}\left(6.5 \mathrm{mg} \cdot \mathrm{L}^{-1}\right), \mathrm{C}\left(13 \mathrm{mg} \cdot \mathrm{L}^{-1}\right)$ and control. Observations in the end of treatment showed a significant difference to hepatopankreas organ histology in each treatment which at the higher concentrations indicates that the more tissue damage visible on hepatopankreas also seen significant changes seen in the tubules hepatopankreatik mangrove crab ( $S$. serata) the vacuole is more established, the epithelium appears irregular, loss of star shape in the lumen.

Keywords: Phenol, hepatopancreas, mangrove crab

\section{PENDAHULUAN}

Fenol dan senyawa fenol dapat menjadi salah satu bahan pencemar air yang masuk ke alam dan masuk ke dalam perairan melalui limbah cair dari berbagai industri antara lain industri batubara, manufaktur fenol, farmasi, resin, cat, tekstil, kulit, petrokimia, pulpmill [1], limbah

\footnotetext{
* Alamat korespondensi:

Agung Pramana Warih Mahendra

email : agung_pramana@ub.ac.id

Alamat : Fakultas MIPA Universitas Brawijaya, Jl. Veteran, Malang, 65145
}

fenol juga dapat berasal dari pestisida non spesifik, herbisida, bakterisida dan fungisida [2] maupun berasal dari berbagai proses industri yang digunakan pada gasifikasi batubara dan kilang minyak [1]. Baku mutu yang sesuai dengan ketentuan PP 82/2001, Sungai Kelas III, besarnya konsentrasi fenol maksimum yang diperbolehkan adalah 0,001 mg. $\mathrm{L}^{-1}$ [3]. Hadirnya fenol yang melebihi batas ambang dalam ekosistem perairan dapat menjadi stresor kimia bagi organisme akuatik, termasuk juga bagi kepiting bakau yang hidup di ekosistem muara [4], oleh 
karena muara (estuaria) merupakan daerah pertemuan antara air tawar dari perairan sungai dan air laut sehingga berpotensi mengandung bahan kimia antropogenik. Hal tersebut dapat terjadi dikarenakan fenol yang terdapat pada limbah sungai pada akhirnya akan mengalir menuju muara sebagai akhir pembuangan [5].

Kepiting bakau (Scylla spp.) merupakan invertebrata yang umum digunakan dalam studi ekotoksisitas polutan dengan berbagai alasan berikut: (1) memiliki distribusi luas di lingkungan muara yang dimanfaatkan sebagai daerah pembibitan untuk pakan, pertumbuhan dan perkembangan (2) bersifat semi pelagik di alam, (3) sensitif terhadap polutan, (4) tersedia sepanjang tahun sehingga meminimalkan kesulitan yang terlibat dalam lokasi dan pengambilan sampel di lapangan, (5) dapat diaklimatisasikan pada kondisi laboratorium dengan mudah [4]. Berdasarkan respon organisme, terbagi dalam efek lethal dan sublethal. Efek letal akan secara langsung berdampak pada kematian individu dalam waktu singkat pada satu kali kesempatan. Sedangkan efek sublethal merupakan pengaruh bahan toksik akibat perlakuan yang belum mematikan dalam selang waktu yang cukup lama [6]. Konsentrasi sublethal telah banyak digunakan untuk mengevaluasi toksisitas polutan dalam air berbagai organisme. Untuk mengetahui efek sublethal dari paparan bahan toksik, perubahan histologi pada organisme akuatik tersebut juga merupakan biomarker yang sangat baik terhadap toxican karena merupakan gambaran hasil biokimia dan perubahan fisiologis. Tanggapan histositologi relatif mudah untuk menentukan dan bisa berkaitan dengan kesehatan individu yang memungkinkan pengembangan monitoring lebih lanjut [7].

Hepatopankreas yang merupakan organ pencernaan pada kepiting yang juga memiliki fungsi penting, termasuk fungsi absorpsi yang ditandai oleh sel mikrovili menunjukkan sebuah penyerapan [8], sekresi enzim $[9,10]$, penyimpanan nutrisi, metabolisme, tempat sintesis vitellogenin selain ovarium, serta detoksifikasi [8, 10]. Sebagai organ utama detoksifikasi xenobiotik pada kelas krustasea, hepatopankreas sangat sensitif terhadap perubahan fisiologis dan lingkungan [8]. Perubahan histologi pada organisme akuatik tersebut merupakan biomarker yang sangat baik terhadap toxican karena merupakan gambaran hasil biokimia dan perubahan fisiologis. Oleh karena itu, penelitian ini bertujuan untuk menilai sejauh mana konsentrasi sublethal fenol terhadap perubahan histologi insang dan hepatopankreas kepiting bakau (Scylla serata), sehingga diharapkan informasi ini dapat diintegrasikan sebagai salah satu sistem peringatan dini (early warning) untuk memantau sejauh mana pencemaran fenol dalam perairan dalam upaya untuk menghindari dampak yang lebih jauh pada ekosistem perairan terutama estuaria dan terlebih lagi terhadap populasi manusia.

\section{METODE PENELITIAN \\ Aklimasi}

Aklimasi Sebelum uji toksisitas, kepiting bakau (S. serata) terlebih dahulu diaklimatisasikan dalam kondisi laboratorium selama 6-8 hari. Kepiting uji yang berukuran panjang $9 \pm 0,5 \mathrm{~cm}$ dan lebar $6 \pm 0,5 \mathrm{~cm}$ dengan berat rata-rata $65-75$ gram dipelihara dalam aquarium kaca $40 \times 25 \times 20$ $\mathrm{cm}$ dengan volume 10 liter air laut salinitas $25 \%$, kepadatan 10 ekor kepiting per akuarium [4]. Aklimatisasi tersebut di kondisi laboratorium yang terkendali dengan aerasi konstan [12]. Kepiting bakau diberi pakan dengan moluska dan udang sekali sehari. Pengisian air dilakukan secara rutin setiap 24 jam untuk menghindari residu toksisitas. Suhu, salinitas dan derajat keasaman $(\mathrm{pH})$ dimonitor secara rutin demikian juga dengan oksigen terlarut (DO). Fotoperiodik 12 jam gelap dan 12 jam terang juga diberikan. Kondisi pasang surut disimulasikan di laboratorium dengan meningkatkan dan menurunkan tingkatan air di dalam setiap durasi 12 jam [11].

\section{Uji Toksisitas Fenol di Laboratorium}

Setelah aklimasi dengan kondisi laboratorium, uji toksisitas dilakukan untuk menentukan konsentrasi median ( $\mathrm{LC}_{50}$ ) fenol pada kepiting bakau ( $S$. serrata). Penentuan LC $_{50}$ dilakukan untuk mendapatkan nilai ambang batas konsentrasi median toksisitas fenol pada kepiting bakau. Masing-masing kepiting bakau dibagi menjadi beberapa kelompok dan setiap kelompok berisi 10 kepiting dalam kaca akuarium berisi air laut salinitas 22\%o, dalam tiga kali replikasi. Larutan stok, dibuat konsentrasi fenol yang diinginkan untuk menentukan toksisitas kepiting bakau. Selama uji toksisitas berlangsung, tidak dilakukan pemberian pakan [4]. Kepiting secara rutin diperiksa mortalitasnya. Kepiting yang mengalami kematian langsung dibuang untuk menghindari toksisitas tambahan dan kualitas air yang jelek [12]. Data mortalitas diolah 
dengan regresi linier $(\mathrm{Y}=\mathrm{a}+\mathrm{bx})$ untuk mendapatkan nilai LC $_{50}$ (96 jam). Selama perlakuan percobaan, wadah uji ditutupi oleh tutup untuk mencegah pengeringan lewat atmosfer [12].

\section{Histologi Organ Hepatopankreas}

Adapun pembuatan preparat histologi dan histopatologi meliputi tahap parafinasi atau embedding dengan langkah pertama adalah pengirisan jaringan dengan ukuran $0,5 \times 0,5 \mathrm{~cm}^{2}$, perendaman dalam larutan fiksatif, yaitu formalin $10 \%$ selama 24 jam sampai tak terbatas, diikuti dengan perendaman dalam alkohol $70 \%$, $80 \%, 90 \%, 95 \%$, alkohol absolut I, II, xylol I, xylol II, masing-masing 2 jam. Kemudian perendaman dengan menggunakan parafin I, parafin II selama 1 jam. Lalu proses embedding atau pemblokkan dilakukan dengan cara memasukkan jaringan dalam cetakan berisi parafin cair menggunakan embedding machine "LEICA EG 1120". Pendinginan hingga mengeras dengan menggunakan embedding machine LEICA $1150 \mathrm{C}$ selanjutnya disimpan dalam suhu kamar selama 24 jam.

Tahap kedua adalah tahap deparafinasi yakni pemotongan blok parafin yang berisi jaringan dipotong dengan menggunakan mikrotom dengan ketebalan 5 mikron. Lalu jaringan yang terpotong diletakkan pada air hangat dalam Tissue Float Bath untuk mencegah hasil pemotongan melengkung. Selanjutnya diletakkan diatas gelas obyek lalu dikeringkan hingga jaringan menempel sempurna pada permukaan gelas obyek. Kemudian dilakukan pencelupan secara berturut-turut pada larutan xylol I dan II; alkohol absolut I dan II; alkohol 99\%, 90\%, 80\%, $70 \%$ masing-masing selama 3 menit. Lalu dilakukan pencelupan dalam aquadest selama 5 menit. Sedangkan tahapan ketiga adalah tahap pewarnaan, tahapan ini dimulai dengan pencelupan dalam larutan pewarna haematoxilin sampai hasil terbaik, apabila warna terlalu pekat, rendam beberapa detik dengan $1 \% \mathrm{HCL}$ dalam alkohol $70 \%$, kemudian bilas dengan air mengalir selama 5-30 menit dilanjutkan dengan proses pewarnaan II dengan eosin selama 5-30 menit lalu bilas dengan akuades kemudian untuk pengecatan mengunakan wright dengan metode yang sama dengan haematoxilin. Tahapan selanjutnya adalah dehidrasi yakni pencelupan kembali secara berturut-turut pada larutan alkohol 70\%, 80\% selama 30 menit; alkohol 90\%, 95\% selama 1 menit dilanjutkan alkohol absolut I, Il selama 1 menit, kemudian diikuti tahapan clearing dengan proses pencelupan dalam xylol I dan xylol II selama 2 menit. Tahapan akhir dari teknik histologi adalah mounting dimana preparat di lem dengan menggunakan albumin meyer, kemudian ditutup dengan cover glass. Hindari terjadinya gelembung. Lalu dibiarkan dalam suhu ruangan sampai lem mengering, kemudian diamati di bawah miskroskop.

\section{HASIL DAN PEMBAHASAN}

Uji Toksisitas Akut LC $_{50}$ (96 Jam) Bahan Toksik Fenol Terhadap Kepiting Bakau (S. serata)

Uji toksisitas akut LC $_{50}$ (96 jam) fenol terhadap kepiting bakau (S. serata) dilakukan untuk menentukan lethal concentration $50 \%$ digunakan lima perlakuan konsentrasi yang berbeda yakni perlakuan A (16 mg. $\left.\mathrm{L}^{-1}\right), \mathrm{B}$ (32 $\left.\mathrm{mg} \cdot \mathrm{L}^{-1}\right), \mathrm{C}\left(64 \mathrm{mg} \cdot \mathrm{L}^{-1}\right), \mathrm{D}\left(128 \mathrm{mg} \cdot \mathrm{L}^{-1}\right)$ dan kontrol (tanpa perlakuan). Pada uji toksisitas akut tersebut, persentase mortalitas kepiting bakau (S. serata) tertinggi adalah pada perlakuan $D$ (100\%) kemudian diikuti perlakuan C (70\%), B (50\%), A(40\%), dan K (0\%). Berdasarkan perhitungan dengan analisis probit maka dapat diketahui nilai LC $_{50}$ (96 jam) fenol terhadap kepiting bakau (S. serata) adalah $26 \mathrm{mg} . \mathrm{L}^{-1}$. Data perhitungan penentuan konsentrasi LC $_{50}$ (96 jam) fenol terhadap kepiting bakau ( $S$. serata) berdasarkan analisis probit ditunjukkan pada Tabel 1.

Tabel 1. Perhitungan penentuan konsentrasi $L_{50}(96$ jam) fenol terhadap kepiting bakau (S. Serata) berdasarkan analisis probit

\begin{tabular}{cccc}
\hline $\begin{array}{c}\text { Konsentrasi } \\
(\mathrm{ppm})\end{array}$ & $\begin{array}{c}\text { Log } \\
\text { Konsentrasi }\end{array}$ & $\begin{array}{c}\text { Persen } \\
\text { Kematian (\%) }\end{array}$ & $\begin{array}{c}\text { Nilai } \\
\text { probit }\end{array}$ \\
\hline 16 & 1,2041 & 40 & 4,75 \\
32 & 1,5051 & 50 & 5,00 \\
64 & 1,8062 & 70 & 5,52 \\
128 & 2,1072 & 100 & 8,09 \\
\hline
\end{tabular}

Persamaan regresi yang diperoleh dari data diatas adalah $Y=3,5012 X+0,0433(r=0,8871)$. Nilai $\mathrm{LC}_{50}$ (96 jam) diperoleh dengan cara memasukan nilai probit 5,00 (\% kematian 50\%) sebagai variabel $\mathrm{Y}$ kedalam persamaan regresi tersebut, sehingga didapatkan median konsentrasi letal $50 \% \quad\left(\mathrm{LC}_{50}\right)$ selama 96 jam fenol terhadap kepiting bakau (S. serata) sebesar $26 \mathrm{mg} \cdot \mathrm{L}^{-1}$.

\section{Uji Toksisitas Sublethal Fenol terhadap Kepiting Bakau (S. serata)}

Konsentrasi perlakuan yang digunakan untuk uji toksisitas sublethal tersebut mengacu pada nilai LC $_{50}-96$ jam yang telah didapatkan dari uji toksisitas akut. Selama penelitian berlangsung 
pergantian media uji sehari sekali. Pemberian pakan kepiting bakau (S. serata) dilakukan 2 kali sehari, yaitu pagi dan sore. Kepadatan kepiting uji adalah lima ekor kepiting bakau (S. serata) per unit percobaan, yang diisi 5 liter air payau dengan salinitas sebesar 22 ppt. Parameter kualitas air yang diamati adalah, oksigen terlarut (DO), suhu dan derajat keasaman ( $\mathrm{pH}$ ) yang diamati setiap hari. Perlakuan pada uji toksisitas sublethal adalah berdasarkan nilai sublethal atau setengah nilai $\mathrm{LC}_{50}-96$ jam ke seri tingkatan konsentrasi yang lebih rendah. Konsentrasi fenol yang digunakan untuk uji toksisitas sublethal selama 7 hari adalah $1 / 16,1 / 4$ dan $1 / 2$ dari $\mathrm{LC}_{50^{-}}$ 96 jam. Jadi konsentrasi perlakuan pada uji toksisitas sublethal adalah sebagai berikut: kontrol (tanpa perlakuan), perlakuan A (1,62 mg. $\left.\mathrm{L}^{-1}\right)$, perlakuan $B\left(6,5 \mathrm{mg} \cdot \mathrm{L}^{-1}\right)$, perlakuan C (13 $\left.\mathrm{mg} \cdot \mathrm{L}^{-1}\right)$. Pengamatan yang dilakukan pada uji toksisitas sublethal adalah histologi organ hepatopankreas kepiting bakau (S. serata).

\section{Histologi Organ Hepatopankreas setelah Pemaparan Konsentrasi Sublethal Fenol}

Berdasarkan pengamatan di bawah mikroskop cahaya tampak struktur umum dari tubulus hepatopancreatik kepiting bakau ( $S$. serata) pada tiap perlakuan ditunjukkan oleh Gambar 1.

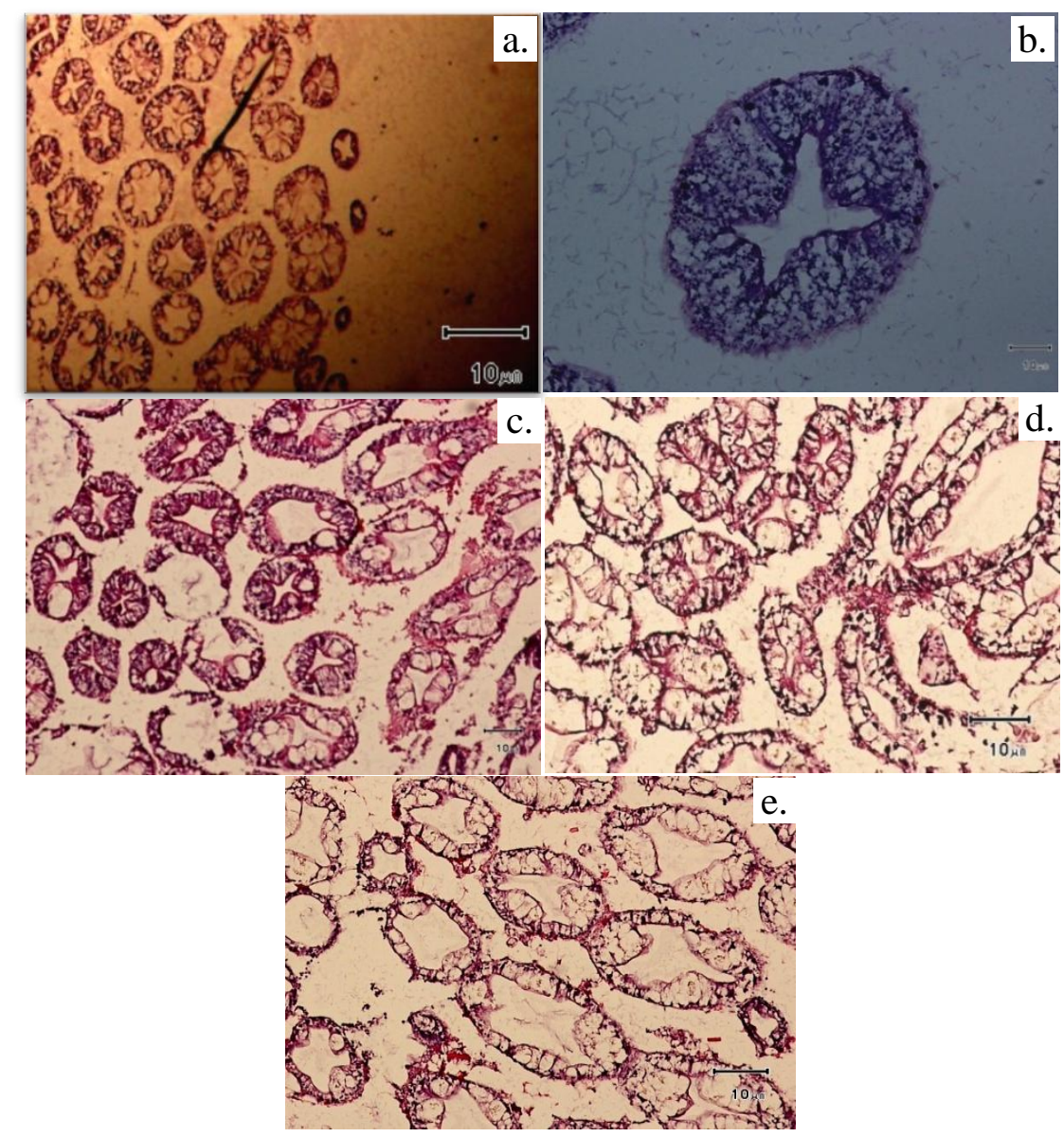

Gambar 1. Gambaran histologi hepatopankreas kepiting bakau (S. serata) setelah akhir perlakuan pemaparan konsentrasi sublethal fenol. Keterangan: a,b. Kontrol; c. Perlakuan dengan fenol konsentrasi konsentrasi $1,62 \mathrm{mg} . \mathrm{L}^{-1}$; d. Perlakuan dengan fenol konsentrasi konsentrasi 6,5 mg. $\mathrm{L}^{-1}$; e. Perlakuan dengan fenol konsentrasi konsentrasi 13 mg..$^{-1}$; Skala bar: $10 \mu$.

Berdasarkan hasil pengamatan, terdapat perubahan yang signifikan yang terlihat pada tubulus hepatopankreatik kepiting bakau ( $S$. serata) yang terpapar konsentrasi sublethal fenol yang berbeda selama tujuh hari bila dibandingkan dengan kontrol (tanpa perlakuan). Disamping itu juga, terlihat perbedaan pada masing-masing perlakuan. Perubahan histologi yang terlihat pada organ hepatopankreas kepiting bakau ( $S$. serata) adalah membran hepatopankreas tampak kusut dan vakuola lebih terbentuk. Selain itu, epitel tampak bergelombang, bahkan seperti tidak beraturan dan pada konsentrasi sublethal fenol yang 
semakin tinggi, yakni perlakuan C (13 mg. $\left.\mathrm{L}^{-1}\right)$ dan bentuk bintang pada lumen sudah tidak terlihat jelas dan vakuola semakin terlihat jelas.

\section{Pembahasan}

Hepatopankreas merupakan organ yang sangat sensitif terhadap pengaruh pencemaran, sehingga organ ini sering digunakan untuk memonitor efek dari berbagai toksikan. Efek dari paparan beberapa perlakuan konsentrasi sublethal fenol melalui teknik histologis untuk mengetahui perubahan jaringan hepatopankreas dari kepiting bakau ( $S$. serata) di amati pada penelitian ini. Teknik histopatologi merupakan teknik yang cepat, sensitif, handal dan relatif murah sebagai alat penilaian terhadap respon stres dari bahan toksik xenobiotik. Perubahan dan evaluasi manifestasi histopatologis memberikan wawasan informasi terhadap tingkat stres, kerentanan dan adaptif kemampuan organisme menghadapi stres. Perubahan histopatologis memberikan evaluasi tingkat stres, kerentanan dan kemampuan adaptif organisme terhadap stres, seperti halnya pada organ hepatopankreas kepiting bakau ( $S$. serata). Hal tersebut menunjukkan bahwa organ tersebut sangat bereaksi terhadap perubahan lingkungan [13].

Sebagian besar toksikan masuk melaui darah kedalam tubuh organime melalui alat pencernaan yang kemudian diabsorpsi dan dibawa ke hepar. Organ tersebut berfungsi sebagai organ utama yang penting dalam regulasi, metabolisme dan detoksifikasi racun oleh xenobiotik yang bersifat toksik. Xenobiotik atau senyawa asing didalam hepar dapat mengalami detoksifikasi tetapi juga dapat dibioaktifkan menjadi lebih toksik. Fungsi hepar tersebut dapat terganggu apabila ada gangguan proses metabolisme karena adanya senyawa bersifat racun, termasuk fenol yang secara kuantitatif mempengaruhi aktivitas enzim metabolisme di zona hepar. Untuk itu hepar memiliki peranan penting sebagai penjelasan profil metabolik fenol [14]. Pada organisme kepiting, xenobiotik masuk melalui air, sedimen ataupun makanan melalui insang kemudian menumpuk pada organ kaya lemak yakni hepatopankreas. Hepatopankreas crustacea memiliki banyak fungsi yang terkait seperti halnya organ hati maupun pankreas pada vertebrata yang meliputi sintesis dan sekresi enzim pencernaan, penyerapan nutrisi, dan akumulasi gizi cadangan [15]. Hepatopankreas tidak hanya merupakan organ pencernaan yang memiliki kemampuan penyerapan, pencernaan, penyimpanan, dan sekresi, tetapi juga besar situs di mana biotransformasi dan detoksifikasi alami pada kelas krustasea. Rute toksik selama metabolisme merupakan hal penting yang harus diperhatikan menentukan pilihan organ untuk mengamati efek dari pengaruh xenobiotik serta menunjukkan umum dan tanggapan khusus untuk tertentu stres. Hepatopankreas pada dasarnya terdiri tubulus bercabang dan berbagai jenis lapisan sel epitel tubulus. Oleh karena itu, kemungkinan bahwa paparan bahan kimia berbahaya (xenobiotik) akan tercermin dalam perubahan struktur tubulus sel epitel [16]. Sehingga diharapkan informasi gambaran lesi akibat efek toksik tersebut dapat menjadi biomarker histopatologis (histological biomarker) sebagai upaya peringatan dini (early warning) pencemaran fenol yang mengancam estuaria.

\section{DAFTAR PUSTAKA}

[1] Saha N.C., Bhunia F., dan Kaviraj A. 1999. Toxicity of Phenol to Fish and Aquatic Ecosystems. Bulletin of Environmental Contamination and Toxicology. 63: 195.202.

[2] Gupta S., Dalela R.C., dan Saxena P.K. 1983. Effect of phenolic compounds on in vivo activity of transaminases in certain tissues of the fish of the fish Notopterus notopterus. Environ. Res. 32: 8-13.

[3] Herawati N., Purwanto, and Hadiyarto A. 2007. Analisis risiko lingkungan aliran Lumpur Lapindo ke badan air (studi kasus Sungai Porong dan Sungai Aloo Kabupaten Sidoarjo). Program Studi Magister Ilmu Lingkungan Pasca Sarjana. Universitas Diponegoro. Semarang.

[4] Vijayavel K., Gopalakrishnan S., Thiagarajan R., dan Thilagam H. 2008. Immuno-toxic Effects of Nickel in the Mud Crab Scylla serrata. Fish \& Shellfish Immunology. 26 (1): 133-139.

[5] Abdel-Hameid N.H. 2007. Physiological and Histopathological Alterations Induced by Phenol Exposure in Oreochromis aureus Juveniles. Turkish Journal of Fisheries and Aquatic Sciences. 7: 131-138.

[6] Connell D.W. and Milller G.J. 1995. Kimia dan Ekotoksikologi Pencemaran. Terjemahan: Yanti Koestoer. Penerbit Universitas Indonesia Press. Jakarta. 52-337.

[7] Larsson U., Elmgren R., and Wulff F. 1985. Eutrophication and the Baltic Sea: Causes and consequences. Ambio. 14: 10-14. 
[8] Sousa L.G., and Petriella A.M. 2007. Functional morphology of the Hepatopancreas of Palaemonetes argentinus (Crustacea: Decapoda): Influence of environmental pollution. Revista de Biologia Tropical. 55(1):78-86.

[9] Ceccaldi H.J. 1989. Anatomy and physiology of digestive tract of Crustaceans Decapods reared in aquaculture. Advances in Tropical Aquaculture, Workshop at Tahiti, French Polynesia. Chapter 26: 243-259.

[10] Zeng H., Ye H., Li S., Wang G., and Huang J. 2010. Hepatopancreas cell cultures from Mud Crab Scylla paramamosain. In Vitro Cellular \& Development Biology-Animal. 46: 431-437.

[11] Saha S., Ray M., and Ray S. 2010. Screening of phagocytosis and intrahemocytotoxicity in arsenic exposed crab as Innate immune response. Asian Journal Experimental Biological Sciences. 1: 47-54.

[12] Saha P., Selvan V.T., Mondal S.K., Mazumder U.K., Gupta M. 2008. Antidiabetic and antioxidant activity of Methanol extract of Ipomoea reptans poir aerial parts in Streptozotocin induced diabetic rats. Pharmacologyonline. 1: 409-421.

[13] Sousa L.G. and Petriella A.M. 2007. Functional morphology of the hepatopancreas of Palaemonetes argentinus (Crustacea: Decapoda): influence of environmental pollution. Revista de Biología Tropical. 55: 79-86.

[14] Medinsky M.A., Kenyon E.M., and Schlosser P.M. 1995. Benzene: a case study in parent chemical and metabolite interactions. Toxicology. 105 (2-3): 225-233.

[15] Gibson O. and Barker P.L. 1979. The decapod hepatopancreas. Oceanography and Marine Biology Annual Review. 17: 285346.

[16] Bhavan P.S. and Geraldine P. 2000. Histopathology of the hepatopancreas and gills of the prawn Macrobrachium malcolmsonii exposure to endosulfan. Aquatic Toxicology. 50(4): 331-339. 